\title{
MICROALGAE HARVESTING: A REVIEW
}

\author{
Alexandra KUCMANOVÁ ${ }^{1}$, Kristína GERULOVÁ ${ }^{1}$ \\ ${ }^{1}$ SLOVAK UNIVERSITY OF TECHNOLOGY IN BRATISLAVA, \\ FACULTY OF MATERIALS SCIENCE AND TECHNOLOGY IN TRNAVA, \\ INSTITUTE OF INTEGRATED SAFETY \\ ULICA JÁNA BOTTU 2781/25, 91724 TRNAVA, SLOVAK REPUBLIC \\ e-mail: alexandra.kucmanova@stuba.sk,kristina.gerulova@stuba.sk, \\ Received: 14.05.2019, Accepted: 17.06.2019, Published: 25.07.2019
}

\begin{abstract}
Microalgae are photosynthetic autotrophic microscopic organisms growing in a range of aquatic and terrestrial habitats. They produce a huge complex of compounds in their surroundings which are of important use to humans. Their commercial use lies in human nutrition, animal and aquatic feed, in cosmetics products, natural pigments, pharmaceutical industry, bio-fertilizer for extracting high-value molecules, stable isotope biochemicals, and for the synthesis of antimicrobial, antiviral, antibacterial and anticancer drugs. Therefore, it is necessary to develop a simple, effective and economically advantageous method for harvesting the algal products. Magnetic separation is a simple separation process. Different synthesis methods have been used by researchers to obtain magnetic particles of varying size and shapes according to the algae to be studied. Chemical co-precipitation method has been the most commonly used method, which helps in synthesizing magnetic particles of the micro to nano range. Naked, coated and surface modified are the general types of magnetic particles used for algal harvesting with its own advantages and disadvantages.
\end{abstract}

\section{Key words}

Harvesting, microalgae, magnetite, nanoparticles

\section{INTRODUCTION}

Photosynthetic protists, also called microalgae, have been systematically studied for more than a century. However, only recently broad biotechnological applications have fostered a novel wave of research on their potentialities as sustainable resources of renewable energy as well as valuable industrial and agro-food products. In any case, intense research and the application of systems of the biology and genetic engineering techniques are absolutely essential to reaching the full potential of microalgae as cell-factories of bio-based products, and thus contribute significantly to solving the problems of bio-sustainability and energy shortage [43]. 
Algae grow in a range of aquatic habitats, including lakes, pounds, rivers, oceans, and even wastewater. They can tolerate a wide range of temperatures, salinities, and $\mathrm{pH}$ values; different light intensities and conditions in reservoirs or deserts and can grow alone or in symbiosis with other organisms. Algae are broadly classified as Rhodophyta (red algae), Phaeophyta (brown algae), and Chlorophyta (green algae), and by size as macroalgae (seaweed) or microalgae [24]. The microalgae are divided into four groups:

1. Cynaobacteria (blue-green algae),

2. Rhodophytes (red algae),

3. Chlorophytes (green algae) and

4. Chromophytes (all other algae).

Each group contains hundreds of species and each of these species has thousands of strains [31], [18].

Microalgae are typically single-cell photosynthetic autotrophic microscopic organisms producing proteins, lipids, carbohydrates, pigments, vitamins and minerals. The microalgal proteins are rich in essential amino acids. Microalgal lipids are very suitable for biodiesel production and are also a good source of essential unsaturated fatty acids - so it has potential application to be used as a food and feed ingredient. Microalgae are also a good source of carbohydrates mainly in the form of starch, cellulose, sugar and other polysaccharides, and the biomass carbohydrate contents highly depend on types of species, cultivation, condition and environmental factors. The overall microalgae carbohydrates have good digestibility [3]. Microalgae are ubiquitous. Thus, they can be found almost anywhere on Earth, in fresh water (ponds, puddles, canals, and lakes) and in marine and hyper-saline environments [16].

Microalgae use the carbon from air or organic carbon for energy production [31] and produce about $50 \%$ of the atmospheric oxygen [37]. They also need sunlight energy source [40] to synthesize food by converting light energy into chemical energy. $90 \%$ of the light energy is dissipated as heat [1].

The use of algae is very old, and the phycologists are continuously working to get hold of their economic importance and many beneficial as well as harmful economic aspects of algae. Some of the beneficial roles exhibited by the algae are as primary producers, source of food for animals and humans, antibiotics and medicines, purifier of wastewater, biofuels including bioethanol, vegetable oils, biodiesel, bio-oil, bio-syngas, bio-hydrogen (called algae fuel, algal fuel or even third generation biofuel). Compared with the second-generation biofuels, algal fuels have a higher yield: they can produce 30-100 times more energy per hectare compared to terrestrial crops, fertilizer and pollution controller by fixing $\mathrm{CO}_{2}$ [11] [40].

On the other hand, algae increase explosively in a water body to produce "blooms" owing to anthropogenic nutrient runoff and also by changes in environmental conditions favourable for algal growth. The concentration of nitrogen and phosphorus plays the key role in algal growth and bloom formation. Mostly, natural algal blooms have a negative impact on the aquatic environment. They produce hypoxic conditions which threaten the sustainability of aquatic ecosystems [33] and may cause eutrophication [7]. Huge algal biomass release secondary metabolites and toxins or through the physical structure of the algal cells or accumulated biomass affecting co-occurring organisms and altering food web dynamics. It results in decreased water clarity, decreased aesthetic value, oxygen depletion, poisonous water, and death of numerous aquatic organisms, ultimately affecting biodiversity [41].

For large scale cultivation and further applications, its harvesting procedure needs to be enhanced to make the production process of the end product highly affordable. Magnetic nanoparticles have great potential to harvest microalgae as it can easily attract and attach to the algal cell surface forming a layer, which can be harvested quickly under the influence of a magnetic field [6]. 


\section{HARVESTING}

Algae harvesting refers to the separation or detachment of algae from its growth medium. The harvesting method intensely depends on the physiognomies of the micro algae chosen, density and size of the microalgal cell, specifications of the final product and on allowability for reuse of the culture medium [2]. Currently algae harvesting involves mechanical, chemical, biological and electrical based methods, for example coagulation/flocculation, flotation, electrical based processes, filtration and centrifugation [40]. It is very common to combine two or more of these methods to obtain a greater separation rate at lower costs [5]. Each of the following methods has both advantages and disadvantages (see Table 1).

Techniques like flocculation introduce charged particles in the end products, which could be undesirable and requires huge amounts of cationic polymers. For large scale processes like biofuel production, extremely large amounts of microalgal cultures are cultivated and need to be harvested. Centrifuging very high volumes is neither feasible nor affordable [6]. Centrifugation is the predominant method for harvesting microalgae as it does not require addition of chemicals. It can often be used in the secondary dewatering process. However, algal broth often requires preconcentration to reduce energy demands for centrifugation and the associated [50]. Although, centrifugation is an effective and fast method of recovering algal cells, high shear and gravitational forces during centrifugation may harm the cells. This method is not economically viable because of high consumption of energy particularly when large volumes are used [4]. Recovery efficiency is more than $90 \%$ and it is directly dependent on the flow throughput. Centrifugation can be also followed by sedimentation to separate the supernatant [34].

In sedimentation processes in a mass force field, the settling behaviour of particles strongly depends on physicochemical properties, concentration, and size distribution of the particles. Although it is considered to be a low-cost and simple technique, the technique is only suitable for microalgae larger than $70 \mu \mathrm{m}$. For smaller microalgae $(5-20 \mu \mathrm{m})$, flocculants must be used to achieve higher settling velocities [50]. Gravity sedimentation a solid-liquid separation method by which concentrated slurry is settled out under gravitation force and leaving above noticeably clear liquid supernatant; further settling characteristics or slurry formation is governed by sedimentation velocity [30]. Gravity sedimentation is not applicable to all microalgal species and electrical processes consumes excessively high amounts of electrical power [6].

Flotation is often defined as "inverted" sedimentation where gas bubbles fed to the broth provide the lifting force needed for particle transport and separation. This process is commonly applied in wastewater treatment processes and is often preceded by coagulation/flocculation. Given microalgal low density and self-float characteristics, flotation is more effective and beneficial in microalgal removal than in sedimentation. The major advantage of flotation is that it has been proved at large scale although it generally requires the use of flocculants. Other advantages are low space requirements, relatively short operation times and high flexibility with lower initial equipment costs [5]. There are several types of flotation methods which have their own advantages and disadvantages - dissolved air flotation (DAF), dispersed air flotation (Diaf), electroflotation, jet flotation, dispersed ozone flotation (Diof) [4].

In filtration process culture medium or algal suspension is run through a filter or a porous membrane, which retains filtrate (algae slurry) and concentrate (remaining water) is passed through a filter by driving force [30] [34]. In this process, microalgal deposits on the filtration membrane tend to grow thicker throughout the process, increasing resistance and decreasing filtration flux upon a constant pressure drop. This phenomenon (called fouling/clogging) represents the main draw- back associated to filtration methods, increasing their operational costs [5]. Furthermore, it consumes considerable amount of energy due to the application of 
high pressure and liquid velocity [50]. There are many different forms of filtration, such as dead end filtration, microfiltration, ultrafiltration, pressure filtration, vacuum filtration and tangential flow filtration (TFF) [17]. Filtration is only sustainable for harvesting long length microalgae or those forming large colonies [52].

Electrophoresis technique is defined as the movement of charged particles from one end to the other end under the influence of an electric field, which pushes the charged algae to shift out of the tray. This technique is another method which efficiently utilizes and separates the algae without adding any chemicals [12]. Based on negative charge, which occurs naturally, the cells are separated by applying an electric field in the electrophoresis process. The method can be adjusted easily by increasing the electrical power to speed up the segregation process [4]. Fouling of the cathodes and systems getting damaged by high temperatures as a result of high-power requirements, are the main disadvantage of this method. Environmental compatibility, safety, versatility, selectivity, energy efficiency, and cost effectiveness are a few benefits of using this method [34].

\begin{tabular}{|l|l|l|}
\hline \multicolumn{3}{|c|}{$\begin{array}{l}\text { Table 1 Advantages and disadvantages of different harvesting methods applied } \\
\text { to microalgal biomass [5] } \\
\text { [40] }\end{array}$} \\
\hline \multicolumn{1}{|c|}{ Harvesting method } & \multicolumn{1}{|c|}{ Advantages } & \multicolumn{1}{c|}{ Disadvantages } \\
\hline $\begin{array}{l}\text { Chemical coagulation/ } \\
\text { flocculation }\end{array}$ & $\begin{array}{l}\text { - simple and fast method } \\
\text { - no energy requirements }\end{array}$ & $\begin{array}{l}\text { - chemical flocculants may be } \\
\text { expensive and toxic to microalgal } \\
\text { biomass } \\
\text { - recycling of culture medium is } \\
\text { limited }\end{array}$ \\
\hline Auto and bioflocculation & $\begin{array}{l}\text { - inexpensive method } \\
\text { - allows culture medium } \\
\text { recycling } \\
\text { - non-toxic to microalgal } \\
\text { biomass }\end{array}$ & $\begin{array}{l}\text { - changes in cellular composition } \\
\text { - possibility of microbiological } \\
\text { contamination }\end{array}$ \\
\hline Gravity sedimentation & $\begin{array}{l}\text { - simple and the inexpensive } \\
\text { method }\end{array}$ & $\begin{array}{l}\text { - time-consuming } \\
\text { - low concentration of the algal } \\
\text { cake } \\
\text { - possibility of biomass } \\
\text { deterioration }\end{array}$ \\
\hline Flotation & $\begin{array}{l}\text { - generally requires the use of } \\
\text { chemical flocculants }\end{array}$ \\
\hline Electrical based \\
processes
\end{tabular}




\section{Magnetic separation of microalgae}

Algae grown in large amounts need a technique for harvesting that is easy, fast, costeffective and should be ideal for harvesting a range of algal species [6]. With the rapid development of nanotechnology, magnetic nanoparticles are currently being widely studied in water treatment field. It is believed that magnetic nanoparticles $\left(\mathrm{Fe}_{3} \mathrm{O}_{4}\right)$ show the finite-size effect and high ratio of surface-to-volume, resulting in a higher adsorption capacity. In addition, easy separation of loaded magnetic nanoparticles from solution and fast settling velocity can be achieved using an external magnetic field. Many studies have reported on magnetic $\mathrm{Fe}_{3} \mathrm{O}_{4}$ particles coating with organic materials as adsorbent for metal removal, such as chitosan and polyacrylamide. However, few researches have been conducted on the composition of magnetic nanoparticles and coagulant solution to enhance coagulation by the adsorption and magnetic effect of $\mathrm{Fe}_{3} \mathrm{O}_{4}$ nanoparticles [23].

The main advantages of magnetic separation processes are the high efficiency and the low operating costs, together with simple and fast processing. The idea of using magnetic material to process algae and to apply some form of magnetic separator is not new, probably dating back half a century when separation was incorporated into wastewater treatment [14]. Magnetic separation is a simple separation process. For the removal of magnetic contaminants, it simply requires a magnetic separator while for the recovery of a desired product, selective magnetic adsorbents are necessary. The separation is achieved based on the intrinsic paramagnetic movement of the magnetic particle tagged products in the response to the magnetic field [45].

Various synthetic methods have been used to produce magnetite nanoparticles including coprecipitation, microemulsion, laser pyrolysis, and hydrothermal synthesis. The major challenges in synthesis procedure of nanoparticle arise from the point that most production methods contain environment-unfriendly ingredients and because of usage of different kind of raw materials these methods are complicated. These factors result in an increase of production cost as well as environmental impact. Among magnetite synthesis methods, coprecipitation technique in water system represents a beneficial method, as the synthesis process is simple and the environmental impact is relatively low [42]. Figure 1 shows synthesis of magnetic nanoparticles and magnetic harvesting of algae.

Nanoparticles (NPs) are defined as atomic or molecular aggregates with at least one dimension between 1 and $100 \mathrm{~nm}$, having drastically changed physical-chemical properties compared to the bulk material [38]. Nanoparticles used for microalgae harvesting are mainly magnetic nanoparticles (MNPs), because magnetic separation enables fast, automatable, and scalable processing with high harvesting efficiency and low contamination [39]. Besides that magnetic nanoparticles have small size, unique physicochemical properties and low cost of production [22].

Bare (naked), coated and surface modified are the general types of magnetic particles used for algal harvesting [6] with their own pros and cons. 


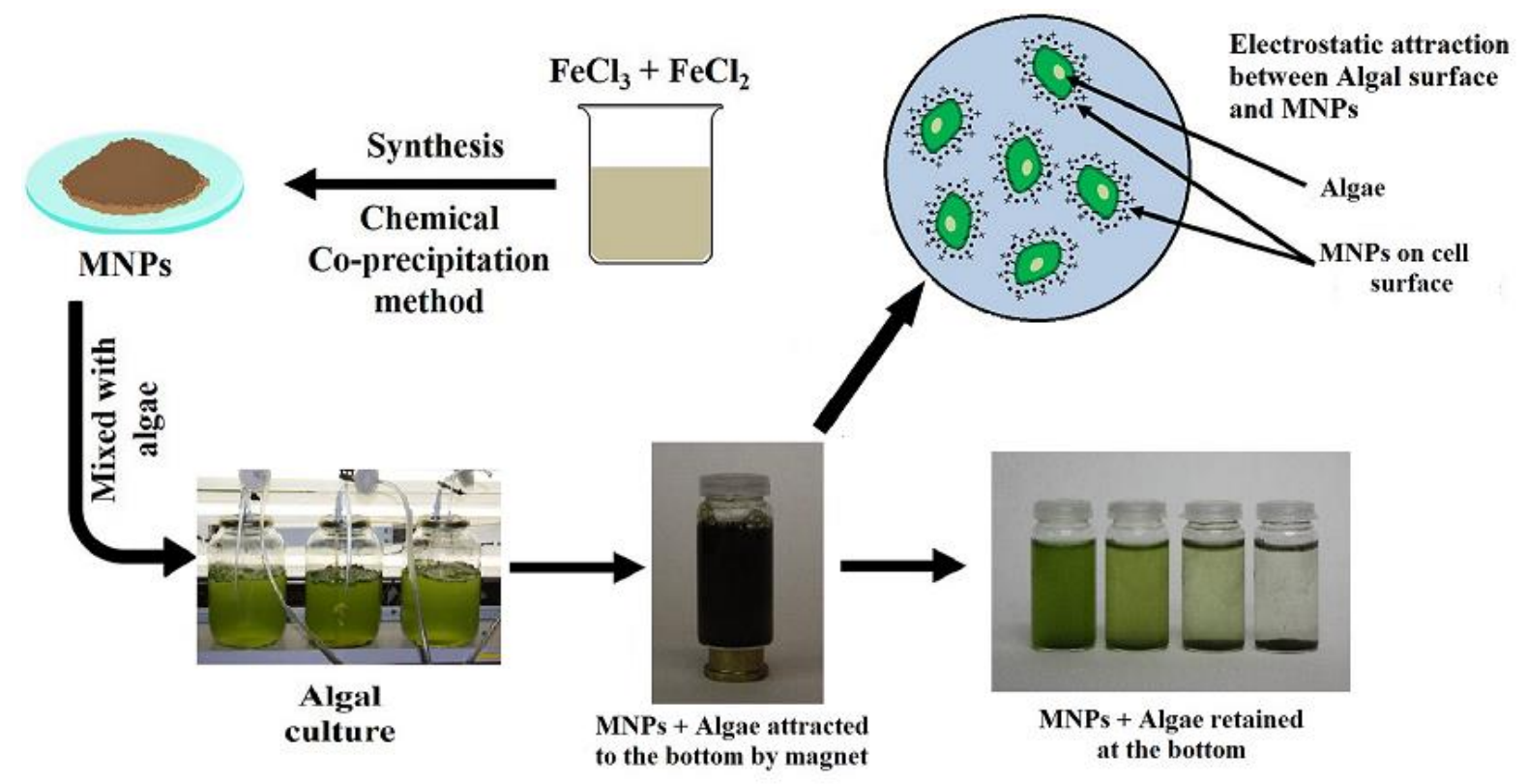

Fig. 1 Synthesis of magnetic nanoparticles (MNPs) and magnetic harvesting of algae [6]

\section{Naked (bare) magnetic particles}

Naked iron oxide nanoparticles which are considered to be low-cost and easy-to-process, were used to study microalgae separation. Successful separation is possible in a broad range of environmental conditions and primarily depends on the nanoparticle-to-microalgae mass ratio, whereas the effect of $\mathrm{pH}$ and ionic strength are less significant when the mass ratio is chosen properly. The weakening of ionic concentration profiles at the interphase due to the successive addition of deionized water leads the microalgae to detach from the nanoparticles. The process works efficiently at the liter scale, enabling complete separation of the microalgae from their medium and the separate recovery of all materials (algae, salts, and nanoparticles). The current lack of profitable harvesting processes for microalgae demands innovative approaches to encourage further development. This application of magnetic nanoparticles is an example of the prospects that nanobiotechnology offers for biomass exploitation. The high affinity of the cell wall for the inorganic surface enables harvesting efficiencies greater than $95 \%$ for Scenedesmus ovalternus and Chlorella vulgaris [14]. $\mathrm{Fe}_{3} \mathrm{O}_{4}$ particles synthesized by chemical co-precipitation were efficient in harvesting the freshwater algal species Botryococcus braunii and Chlorella ellipsoidea [26] [45]. In another work, utilized $\mathrm{Fe}_{3} \mathrm{O}_{4}$ nanoparticles were used for the efficient harvesting of the marine microalgae Nannochloropsis maritima. The recovery efficiency of microalgal cells from the culture medium was more than $95 \%$ at the particle dosage of $120 \mathrm{mg} / \mathrm{L}$ within 4 minutes [20].

It has been confirmed that naked magnetite has ion exchange characteristics and the separation is primarily based on the electrostatic interactions between the magnetite and the algal cells. In addition, Fe ions released from naked iron oxide magnetic microparticles surface may act as flocculating agents and benefit the harvesting process. However, the released ions may increase the metal content in the harvested algal cells and this can influence the downstream refining of algal biomass. For example, the Fe can poison the catalysts for desulfurization and decrease the gasoline yields. For that reason, the choice of magnetic adsorbent should consider the potential influence on the downstream process [45].

$\mathrm{pH}$ value is also a quite important factor influencing zeta potential of nanoparticles which affects the electrostatic interaction for adsorption dramatically. The effect of $\mathrm{pH}$ value on the adsorption between algae cells and nanoparticles was investigated in order to achieve higher 
harvesting efficiency at appropriate $\mathrm{pH}$ value. When $\mathrm{pH}$ value decreases, harvesting efficiency significantly rises. Therefore, a low $\mathrm{pH}$ value is favourable for the adsorption between the algae cells and the nanoparticles attributed to the protonation of the nanoparticles surface [29]. For example, harvesting of Nannochloropsis oceanica at basic $\mathrm{pH}$ and low particle concentration lead to high separation efficiency despite constant stirring speed and time [30].

Very important finding of how to increase harvesting efficiency of microalgae is to add the stirring mechanism for better attachment of the iron oxide nanoparticles and the microalgal cell surface before exposure to the external magnetic field. It is expected that this step can significantly increase harvesting efficiency [6] [47].

Phosphorus ions in the medium are identified as one of the vital factors interfering magnetic microalgal cell harvesting. Magnetit microparticles synthesized by microwave treatment showed phosphorus limited Chlorella vulgaris cells were separated from its suspension at $95 \%$ efficiency than phosphorous repleted cells with 3:1 load of microparticles to cells. Ultrasound mediated demagnetization of separated cells were carried out at $40{ }^{\circ} \mathrm{C}$ assisted with $10 \% \mathrm{H}_{2} \mathrm{SO}_{4}$ treatment and the recovery of demagnetized microalgae was close to $100 \%$. In contrast, applying $10 \% \mathrm{H}_{2} \mathrm{SO}_{4}$ and mixing at room temperature, the cell recovery was very poor (up to $20 \%$ ). Nevertheless, it must be highlighted that the application of acids may not be suitable for all microalgal species and target compounds [35] [47].

\section{Coated and surface modified nanoparticles}

Generally, a microorganism tends to adhere to solid surfaces to minimize the free interfacial energy. In the course of algal adhesion to magnetic particles in an aqueous environment a whole range of interactions such as non-covalent Lifshitz van der Waals forces, electrostatic forces, and acid-base interactions have to be considered [35]. It causes the suppression of harvesting thus the modification of magnetic nanomaterials is of vital importance [28] [30]. Due to negative surface charges on most microalgae, cationic polymers are often used as coating chemicals [50]. Many authors have studied different coatings of magnetic nanoparticles for rapid harvesting of microalgae.

\section{Nanoparticles + Poly-arginine (PA)}

Liu et al. used highly positive long-chain poly-arginine to modify magnetic porous $\mathrm{Fe}_{3} \mathrm{O}_{4}$, and three kinds of poly-arginine with different molecular weights were selected to investigate the effect of molecular weight of poly-arginine on microalgal harvesting. The modification was achieved by first coupling amino silane on $\mathrm{p}-\mathrm{Fe}_{3} \mathrm{O}_{4}$ to obtain free amino groups on the surface; then, amidation was used to link the poly-arginine and the free amino groups, using carbodiimide as dehydrant. Consequently, poly-arginine-modified porous $\mathrm{Fe}_{3} \mathrm{O}_{4}$ microspheres (p- $\mathrm{Fe}_{3} \mathrm{O}_{4} @ \mathrm{PA}$ ) were synthesized. Highly positively charged polymer of long-chain polyarginine provided more active sites and facilitated bridging and trapping for adsorption with negatively charged algae cells. The modification with poly-arginine at an optimal molecular weight could promote harvesting significantly, and the optimal dosage of nanomaterial decreased from $250 \mathrm{mg} \cdot \mathrm{l}^{-1}$ (p- $\mathrm{Fe}_{3} \mathrm{O}_{4}$ ) to10 mg. $\mathrm{l}^{-1}$ (p- $\mathrm{Fe}_{3} \mathrm{O}_{4} @ \mathrm{PA}-2$ ). The results show that the high harvesting efficiency of $\mathrm{p}-\mathrm{Fe}_{3} \mathrm{O}_{4} @ \mathrm{PA}-2 \sim 3$ could be maintained in a wide $\mathrm{pH}$ range due to the high positive charge and stronger force of hydrogen bonding. Further, these nanomaterials could maintain good recycling stability and achieve high harvesting efficiency after 5 regeneration cycles [28].

\section{Nanoparticles + PEI (polyethylenimine)}

Polyethylenimine (PEI) is known for its high density of positive charge and was used to coat the surface of magnetit nanoparticles to bring in cationic charge on the $\mathrm{Fe}_{3} \mathrm{O}_{4}-\mathrm{PEI}$ 
nanocomposites. Polyethylenimine also contains a high concentration of $-\mathrm{NH}_{2}$ groups which can easily react with $-\mathrm{COOH}$ and $-\mathrm{OH}$ groups of the microalgal cell surface, allowing functional magnetic particles with an amine-rich structure to assist with the microalgal recovery. The magnetic nanocomposites were applied to harvest freshwater microalgae Chlorella ellipsoidea. High harvesting efficiency (97\%) was achieved using a nanocomposites dosage of $20 \mathrm{mg} .1^{-1}$ at $120 \mathrm{rpm}, \mathrm{pH}$ value of 4 within 2 minutes. Increasing the temperature resulted in an increase in harvesting efficiency. In contrast, the harvesting efficiency decreased as the $\mathrm{pH}$ value increased due to the competition between the hydroxyl ions and the microalgal cells for the nanocomposite adsorption sites. In addition, the higher nanocomposite dosage provided a larger number of active sites available for the capture of microalgal cells and resulted in a higher harvesting efficiency [19]. Increasing trend of harvesting efficiency of microalgae when the dosage of PEI-coated nanoparticles was also confirmed by other authors [15] [49].

\section{Nanoparticles + Polyamidoamine}

Magnetic iron oxide coated separately with dendrimer (amino-riched polyamidoamine = PANAM) and amino acid was compared for efficient harvesting of oleaginous Chlorella sp. The coating of highly positive branched PANAM dendrimer significantly improved the adsorption between algae cells and nanoparticles compared with micromolecular amino acids, indicating that modification with polymer on magnetic iron oxide nanoparticles is much more in favour of microalgal harvesting than micromolecule. The harvesting efficiency was positively correlated with the coating thickness of dendrimer at $80 \mathrm{mg} \cdot \mathrm{l}^{-1}$ and reached to $95 \%$ within 2 minutes at $\mathrm{pH} 8,0$. The efficiency further improved when $\mathrm{pH}$ brought down to 4 [46].

\section{Nanoparticles + Polyaluminium chloride (PACI) + polyacrylamide (PAM)}

Another study examined the harvesting of oleaginous microalgae Chlorella vulgaris from freshwater where the nanoparticles were coated by polyaluminium chloride (PACl) and polyacrylamide (PAM). Polyaluminium chloride $(\mathrm{PACl})$ is often applied coupled with polyacrylamide (PAM) and the combination has already exhibited better efficiency in removing algae and pollutant during water treatment. Hence, PACl and PAM were selected as the two polymers to combine with natural magnetite. The composite mode and dosing strategy have an intensive impact on cell recovery. The optimum strategy to achieve $99 \%$ harvesting of Chlorella vulgaris in less than $0,5 \mathrm{~min}$ is to dose the composite $\mathrm{PACl} / \mathrm{Fe}_{3} \mathrm{O}_{4}$ first, followed by dosing PAM. It could overcome negative impacts from $\mathrm{pH}$ and algal organic matter. Alkaline environment was more beneficial for microalgal harvesting using either composite $\mathrm{PACl} / \mathrm{Fe}_{3} \mathrm{O}_{4}$ or $\mathrm{PACl} / \mathrm{Fe}_{3} \mathrm{O}_{4}+\mathrm{PAM}$. Moreover, the $\mathrm{pH}$ values of the microalgae broth had nearly no influence on the magnetic floc movement to the bottom. The addition of PAM not only improved the harvesting efficiency to $99 \%$, but also shortened the settling time from 5 minutes ( $\mathrm{PACl} / \mathrm{Fe}_{3} \mathrm{O}_{4}$ ) to less than 0,5 minutes $\left(\mathrm{PACl} / \mathrm{Fe}_{3} \mathrm{O}_{4}+\mathrm{PAM}\right)$ under alkaline environment. After the increase in zeta potentials of $\mathrm{PACl} / \mathrm{Fe}_{3} \mathrm{O}_{4}$ is the main reason for the improvement in harvesting. The main mechanism in the $\mathrm{PACl} / \mathrm{Fe}_{3} \mathrm{O}_{4}+\mathrm{PAM}$ process involves charge neutralization of $\mathrm{PACl} / \mathrm{Fe}_{3} \mathrm{O}_{4}$ and bridging and entrapment of PAM. Such strategy can overcome the negative influences of $\mathrm{pH}$ and AOM [50].

\section{Nanoparticles + chitosan}

Lee et al. examined harvesting process of oleaginous microalgae Chlorella sp. by using chitosan- $\mathrm{Fe}_{3} \mathrm{O}_{4}$ nanoparticle composites. Over $99 \%$ of microalgae was harvested by using the composites and the external magnetic field without changing the $\mathrm{pH}$ of culture medium so that it may be reused for microalgal culture without adverse effect on the cell growth. The averaged $\mathrm{pH}$ of the culture medium was $6,90 \pm 0,16$ after harvesting with various ranges of dosage of chitosan- $-\mathrm{Fe}_{3} \mathrm{O}_{4}$ nanoparticles and the efficiency was more than $95 \%$ in the ranges of $\mathrm{pH} 2-12$. 
Depending on the working volume $(20-500 \mathrm{ml})$ and the strength of surface magnetic field (3400-9200 G), the process of harvesting microalgae took only 2-5 minutes. This method also recycles the medium effectively for further cultivation of microalgae. Cell growth in the reused medium that had been used once in CS/MNP harvesting was similar to that of the new medium [25].

\section{Nanoparticles + Poly (diallyldimethylammonium chloride) (PDDA)}

Magnetic graphene oxide (GO) nanocomposite coated with cationic polymer PDDA (diallyldimethylammonium chloride) is also successful method for harvesting of oleaginous microalgae Chlorella sp. High harvesting efficiency of GO-Fe ${ }_{3} \mathrm{O}_{4} / \mathrm{PDDA}$ (graphene oxide nanocomposites coated with PDDA) nanocomposites (approximately $95 \%$ ) could be maintained in a wide $\mathrm{pH}$ range (from 12 to 4 ) due to the highly positive charge and stable property of graphene base. This is very practical in industry production. In addition, by applying a raw/reactivated mixture strategy, nanomaterials could maintain a relatively recycling stability and achieve high harvesting efficiency after 5 cycling times [29].

\section{Nanoparticles + Fumed silica particles}

Flame-derived silica-coated magnetic particles are another example of a promising lowcost alternative to precipitated magnetite and to enhance magnetic separation of microalgae. Cerff et al. focused their study on magnetic separation of fresh water (Chlamydomonas reinhardtii, Chlorella vulgaris) as well as marine algae (Phaeodactylum tricornutum, Nannochloropsis salina) by silica-coated fumed bulk magnetic particles. High separation efficiencies (more than 95\%) were obtained for all examined algae. Complete algae removal was accomplished in only 5 minutes in a high gradient magnetic filter system under flow conditions. High $\mathrm{pH}$, presence of di- and trivalent ions enhanced flocculation and enclosure of magnetic beads into floccules. This resulted in intense increase of separation efficiencies of fresh water and marine algae [8].

\section{Nanoparticles + Plant Polyphenol (PP)}

Zhao et al. studied magnetic harvesting of Chlorella vulgaris by magnetic particles coated with plant polyphenol (PP). Polyphenol was chemically modified by a Mannich reaction followed by quaternization $\left(\mathrm{Fe}_{3} \mathrm{O}_{4} @ \mathrm{Q}-\mathrm{PP}\right)$ in order to improve its affinity to microalgal cells and increase the polymerization capacity. The authors found out that the $\mathrm{Fe}_{3} \mathrm{O}_{4} @ \mathrm{Q}-\mathrm{PP}$ composite $(5,0 \mathrm{~g} / \mathrm{l})$ could directly harvest $91 \%$ of the cells from the culture media. Even if the microalgal culture was in an alkaline environment, the use of the $\mathrm{Fe}_{3} \mathrm{O}_{4} @ \mathrm{Q}-\mathrm{PP}$ resulted in a high efficiency of harvesting. The effective detachment of the magnetic particles from the $\mathrm{Fe}_{3} \mathrm{O}_{4} @$ Q-PP-cell aggregates was reached by ultrasounds application and more than $96 \%$ of magnetit was recovered. The recycled $\mathrm{Fe}_{3} \mathrm{O}_{4} @ \mathrm{Q}-\mathrm{PP}$ also achieved a high harvesting efficiency of the microalgae cells (76\% harvesting efficiency at the tenth cycle) [51].

\section{CONCLUSION}

Microalgae have multiple beneficial characteristics that can potentially be used to overcome some of today's issues [10]. Concerning environmental use, microalgae can play an important role in wastewater treatment, carbon dioxide sequestration [5], eutrophication of surface bodies and oxygen production. Commercial application of microalgae include food supplements, animal feed, biofuel production [11][19], pharmaceutical industry, cosmetics products, natural pigments as well as they can produce different kinds of carotenoid, enzyme polymer, lipid, natural dye, peptide, toxin and sterols, which are used in several industrial 
products [37]. In addition, microalgae have the potential to accumulate high-value substances such as omega-3 fatty acids, vitamins and antibiotics [14][45].

The key phases in the production process for commercial usage are cultivation, biomass harvesting, extraction of the desired components, and production of the desired substances [45].

Efficient harvesting of cultivated algal biomass is prerequisite for their mass production. A particular harvesting method may not be appropriate to recover all forms of algal biomass, consequently screening and identification of an efficient process is extremely needed to harvest the algal culture as per their physicochemical properties, since the harvesting cost may account approximately up to $20-30 \%$ of the total biomass production cost. Moreover, efficient and cost-effective methods of algae harvesting from water is a major problem towards industrial scale processing due to their small size [13][36][39]. As well as culture broths are generally relatively dilute $\left(<0,5 \mathrm{~kg} \cdot \mathrm{m}^{-3}\right.$ dry biomass in some commercial production systems) and hence large volumes need to be handled to recover the biomass. No single harvest method may be suited to every case [32].

Traditional approaches to microalgae harvesting including filtration, electrolysis, floatation, and centrifugation, face the shortcomings of high costs, energy-intensiveness, and complicated procedures [28]. Some energy and economic analyses of these harvesting methods have been made [9][13][21][27][44].

Magnetic separation as a simple method for algae removal has been reported almost forty years ago [8][19]. It can achieve more than $90 \%$ of cell recovery in less than 5 minutes during the harvesting processes of microalgae. The magnetic harvesting combines flocculation and magnetic separation in a single process, offering quick, simple, energy-efficient, and costeffective advantages. In addition, external magnetic field enables to concentrate magnetically modified cells into compact slurry and remove large amounts of bulk liquid in a short time [50].

Both naked and surface-modified magnetic nanoparticles have good performance in magnetic harvesting algae, but their cost-effectiveness in industrial application need further analysis to evaluate their feasibility in practice. From the cost-effectiveness analysis, realized by $\mathrm{Y}$. Xu, Fu and Zhang, showed that the costs of all the surface modified MNPs ranged from $£ 8,9$ to $£ 185,7$ per kg DCW (dry cell weight) which seemed expensive for engineering application [25]. Besides, surface modification also led to the problems of low reactivation efficiency for reuse, causing large amount of MNPs wastes after algae harvesting. The total cost of naked MNPs harvesting was significantly lower as about £3-500 per kg DCW. Further reactivated by ultrasonic/alkaline treatment, the harvesting cost could be further reduced to $£ 0,5-108,0$ per $\mathrm{kg}$ DCW, much lower than surface modified MNPs with bright industrial potentials. Magnetic nanoparticles reactivation significantly reduces the materials consumption and the unit algae harvesting cost, proving itself as a promising method for industrial application. Further research is suggested to keep on investigating cheaper methods for magnetic nanoparticles synthesis and possible cost-effective magnetic nanoparticles reactivation to further reduce algae. The estimated costs of different magnetic harvesting materials and methods are shown in Table 2 [48]. 


\begin{tabular}{|c|c|c|c|c|c|}
\hline MNPs & Algal strain & $\begin{array}{c}\text { Surface } \\
\text { modification }\end{array}$ & $\begin{array}{c}\text { Capacity } \\
(\mathrm{g} \text { DCW/g) }\end{array}$ & Reactivation & $\begin{array}{l}\text { Total cost in } \\
£(\mathrm{~kg} / \mathrm{DCW})\end{array}$ \\
\hline $\begin{array}{c}\text { Iron oxide } \\
\text { magnetic } \\
\text { microparticles }\end{array}$ & Chlorella vulgaris & - & 0,4 & Ultrasound & 89,3 \\
\hline $\begin{array}{c}\mathrm{Fe}_{3} \mathrm{O}_{4} \text { and } \beta- \\
\mathrm{FeOOH} \\
\text { nanorods }\end{array}$ & $\begin{array}{l}\text { Microcystis } \\
\text { aeruginosa }\end{array}$ & - & 3,74 & Ultrasound & 7,0 \\
\hline $\begin{array}{c}\mathrm{Fe}_{3} \mathrm{O}_{4} \text { powder } \\
(<5 \mu \mathrm{m})\end{array}$ & Chlorella sp. KR-1 & - & 0,08 & Alkaline/acid & 4,250 \\
\hline $\mathrm{Fe}_{3} \mathrm{O}_{4}$ & & - & 10,05 & - & 13,0 \\
\hline $\mathrm{Fe}_{3} \mathrm{O}_{4}$ & $\begin{array}{c}\text { Botryococcus } \\
\text { braunii, } \\
\text { Chlorella } \\
\text { ellipsoidea }\end{array}$ & - & $5,83-55,90$ & Solvent & $0,5-4,3$ \\
\hline $\mathrm{Fe}_{3} \mathrm{O}_{4}$ & $\begin{array}{l}\text { Botryococcus } \\
\text { braunii, } \\
\text { Chlorella } \\
\text { ellipsoidea }\end{array}$ & $\begin{array}{l}\text { Polyacrylamide } \\
\text { (CPAM) }\end{array}$ & $\begin{array}{l}21,40- \\
114,80\end{array}$ & - & $10,3-55,0$ \\
\hline $\mathrm{Fe}_{3} \mathrm{O}_{4}$ & Chlorella sp. KR-1 & Chitosan & $0,3-1,0$ & - & $8,9-185,7$ \\
\hline $\mathrm{Fe}_{3} \mathrm{O}_{4}$ & Chlorella sp. & Chitosan & $\sim 1.0$ & - & $\sim 44.8$ \\
\hline $\begin{array}{c}\mathrm{Fe}_{3} \mathrm{O}_{4}, \beta- \\
\mathrm{FeOOH} \text { and } \\
\mathrm{Fe}_{2} \mathrm{O}_{4}\end{array}$ & $\begin{array}{c}\text { Synechocystis, } \\
\text { Stigeoclonium, } \\
\text { Nannochloropsis, } \\
\text { Microcystis }\end{array}$ & - & $0,24-15,50$ & $\begin{array}{l}\text { Ultrasound or } \\
\text { alkaline }\end{array}$ & $1,7-108,0$ \\
\hline
\end{tabular}

Recently, we are increasingly witnessing an excessive environmental pollution caused by plastics/microplastics, antibiotics and drugs that conventional wastewater treatment processes cannot completely remove. Subsequently, these substances enter the body of aquatic organisms where they accumulate. By consuming terrestrial animals, these substances reach next levels of the food chain and adversely affect humans. The ability of algae to remove hard-degradable chemicals from the water or their ability to produce bioactive molecules/compounds together with the implementation of new scientific knowledge and environmental technologies, gives great potential to use magnetic nanoparticles to harvest algae from wastewater or natural waters quickly and efficiently. In addition, magnetic nanoparticles can be also used in other areas, e.g. removal of organic and inorganic pollutants from various environmental matrices (heavy metals, dyes, pesticides, pharmaceuticals), as biosensors or in medicine, etc. On the other hand, the possible negative impact of magnetic nanoparticles in their unpredictable release to nature and their possible negative impact on plants, animals, microorganisms is still not sufficiently explored. That is why it is important to focus research in this direction, too. Hence, we can recognize all the properties and behaviour of magnetic nanoparticles (shape, size and composition of magnetic nanoparticles, type of used medium to dispersion and organism physiology) in nature so we are able to react just in time and to avoid negative impacts on biodiversity. We believe that algae harvesting via magnetic nanoparticles can find its application in practice. 


\section{References}

[1] AGARWAL, P., RITIKA G., AGARWAL, N. 2019. Advances in Synthesis and Applications of Microalgal Nanoparticles for Wastewater Treatment. Journal of Nanotechnology, 2019, 1-9. https://doi.org/10.1155/2019/7392713.

[2] AMARO, H. M., A. GUEDES, C., MALCATA, F. X. 2011. Advances and Perspectives in Using Microalgae to Produce Biodiesel. Applied Energy, 88(10): 3402-3410. https://doi.org/10.1016/j.apenergy.2010.12.014.

[3] ANSARI, F. A., SHEKH, A. Y., GUPTA, S. K., BUX, F. 2017. Microalgae for Biofuels: Applications, Process Contrains and Future Needs. Algal Biofuels: Recent Advances and Future Prospects, 57-76. https://doi.org/10.1007/978-3-319-51010-1.

[4] BAJPAI, P. 2019. Third Generation Biofuels. Springer Nature Singapore Pte Ltd., 2019. 87 p. ISBN 978-981-136-2378-2.

[5] BARROS, A. I., GONÇAlVES, A. L., SIMÕES, M., PIRES, J. C.M. 2015. Harvesting Techniques Applied to Microalgae: A Review. Renewable and Sustainable Energy Reviews 41, 1489-1500. https://doi.org/10.1016/j.rser.2014.09.037.

[6] BHARTE, S., DESAI, K. 2018. Harvesting Chlorella Species Using Magnetic Iron Oxide Nanoparticles. Phycological Research, 67(3), 128-133. https://doi.org/10.1111/pre.12358.

[7] CAI, T., PARK, S. Y., LI, Y. 2013. Nutrient Recovery from Wastewater Streams by Microalgae: Status and Prospects. Renewable and Sustainable Energy Reviews, 19, 360-369. https://doi.org/10.1016/j.rser.2012.11.030.

[8] CERFF, M., MORWEISER, M., DILLSCHNEIDER, R., MICHEL, A., MENZEL, K., POSTEN, C. 2012. Harvesting Fresh Water and Marine Algae by Magnetic Separation: Screening of Separation Parameters and High Gradient Magnetic Filtration. Bioresource Technology, 118, 289-295. https://doi.org/10.1016/j.biortech.2012.05.020.

[9] COLlOTTA, M., CHAMPAGNE, P., MABEE, W., TOMASONI, G., LEITE, G. B., BUSI, L., ALBERTI, M. 2017. Comparative LCA of Flocculation for the Harvesting of Microalgae for Biofuels Production. Procedia CIRP, 61, 756-760. https://doi.org/10.1016/j.procir.2016.11.146.

[10] DARVEHEI, P., BAHRI, P. A., MOHEIMANI, N. R.. 2018. Model Development for the Growth of Microalgae: A Review. Renewable and Sustainable Energy Reviews, 97, 233-258. https://doi.org/10.1016/j.rser.2018.08.027.

[11] DEMIRBAS, A. 2010. Use of Algae as Biofuel Sources. Energy Conversion and Management, 51(12), 2738-2749. https://doi.org/10.1016/j.enconman.2010.06.010.

[12] ENAMALA, M. K., ENAMALA, S., CHAVALI, M., DONEPUDI, J., YADAVALLI, R., KOLAPALLI, B., ARADHYULA, T. V., VELPURI, J., KUPPAM, Ch. 2018. Production of Biofuels from Microalgae - A Review on Cultivation, Harvesting, Lipid Extraction, and Numerous Applications of Microalgae. Renewable and Sustainable Energy Reviews, 94, 49-68. https://doi.org/10.1016/j.rser.2018.05.012.

[13] FASAEI, F., BITTER, J. H., SLEGERS, P. M., van BOXTEL, A. J.B. 2018. Techno-Economic Evaluation of Microalgae Harvesting and Dewatering Systems. Algal Research, 31, 347-362. https://doi.org/10.1016/j.algal.2017.11.038.

[14] FRAGA-GARCÍA, P., KUBBUTAT, P., BRAMMEN, M., SCHWAMINGER, S., BERENSMEIER, S. 2018. Bare Iron Oxide Nanoparticles for Magnetic Harvesting of Microalgae: From Interaction Behavior to Process Realization. Nanomaterials, 8(5), 1 - 17. https://doi.org/10.3390/nano8050292.

[15] GERULOVÁ, K., BARTOŠOVÁ, A., BLINOVÁ, L., BÁRTOVÁ, K., DOMÁNKOVÁ, M., GARAIOVÁ, Z., PALCUT, M. 2018. Magnetic $\mathrm{Fe}_{3} \mathrm{O}_{4}$-Polyethyleneimine Nanocomposites for Efficient Harvesting of Chlorella zofingiensis, Chlorella vulgaris, Chlorella sorokiniana, Chlorella ellipsoidea and Botryococcus braunii. Algal Research, 33, 165-172. https://doi.org/10.1016/j.algal.2018.05.003.

[16] HAMED, I. 2016. The Evolution and Versatility of Microalgal Biotechnology: A Review. Comprehensive Reviews in Food Science and Food Safety, 15(6), 1104-1123. https://doi.org/10.1111/1541-4337.12227. 
[17] HARUN, R., SINGH, M., FORDE, G. M., DANQUAH, M. K. 2010. Bioprocess Engineering of Microalgae to Produce a Variety of Consumer Products. Renewable and Sustainable Energy Reviews, 14(3), 1037-1047. https://doi.org/10.1016/j.rser.2009.11.004.

[18] HOCHMAN, G., ZILBERMAN, D. 2014. Algae Farming and Its Bio-Products. In McCann M., Buckeridge M., Carpita N. (eds) Plants and BioEnergy. Advances in Plant Biology, 4, Springer, New York, pp. 49-64. https://doi.org/10.1007/978-1-4614-9329-7.

[19] HU, Y.-R., GUO, CH., WANG, F., WANG, S.-K., PAN, F., LIU, CH.-Z. 2014. Improvement of Microalgae Harvesting by Magnetic Nanocomposites Coated with Polyethylenimine. Chemical Engineering Journal, 242, 341-347. https://doi.org/10.1016/j.cej.2013.12.066.

[20] HU, Y.-R., WANG, F., WANG, S.-K., LIU, CH.-Z., GUO, CH. 2013. Efficient Harvesting of Marine Microalgae Nannochloropsis maritima Using Magnetic Nanoparticles. Bioresource Technology 138, 387-390. https://doi.org/10.1016/j.biortech.2013.04.016.

[21] CHRISTENSON, L., SIMS, R. 2011. Production and Harvesting of Microalgae for Wastewater Treatment, Biofuels, and Bioproducts. Biotechnology Advances, 29(6), 686-702. https://doi.org/10.1016/j.biotechadv.2011.05.015.

[22] JIANG, B., LIAN, L., XING, Y., ZHANG, N., CHEN, Y., LU, P., ZHANG, N. 2018. Advances of Magnetic Nanoparticles in Environmental Application: Environmental Remediation and (Bio)Sensors as Case Studies. Environmental Science and Pollution Research, 25(31), 3086330879. https://doi.org/10.1007/s11356-018-3095-7.

[23] JIANG, Ch., WANG, Ren, MA, W. 2010. The Effect of Magnetic Nanoparticles on Microcystis aeruginosa Removal by a Composite Coagulant. Colloids and Surfaces A: Physicochemical and Engineering Aspects, 369(1-3), 260-267. https://doi.org/10.1016/j.colsurfa.2010.08.033.

[24] KHAN, M. I., SHIN, J. H., KIM, J. D. 2018. The Promising Future of Microalgae: Current Status, Challenges, and Optimization of a Sustainable and Renewable Industry for Biofuels, Feed, and Other Products. Microbial Cell Factories 17(1), 1-21. https://doi.org/10.1186/s12934-018-0879$\mathrm{x}$.

[25] LEE, K., LEE, S. Y., NA, J.-G., JEON, S.-G., PRAVEENKUMAR, R., KIM, D.-M., CHANG, W.-S., OH, Y.-K. 2013. Magnetophoretic Harvesting of Oleaginous Chlorella Sp. by Using Biocompatible Chitosan/Magnetic Nanoparticle Composites. Bioresource Technology, 149, 575578. https://doi.org/10.1016/j.biortech.2013.09.074.

[26] LEE, K., LEE, S. Y., PRAVEENKUMAR, R., KIM, B., SEO, J. Y., JEON, S. G., NA, J.-G., PARK, J.-Y., KIM, D.-M., OH, Y.-K. 2014. Repeated Use of Stable Magnetic Flocculant for Efficient Harvest of Oleaginous Chlorella Sp. Bioresource Technology, 167, 284-290. https://doi.org/10.1016/j.biortech.2014.06.055.

[27] LEITE, G. B., ABDELAZIZ, A. E.M., HALLENBECK, P. C. 2013. Algal Biofuels: Challenges and Opportunities. Bioresource Technology, 145, 134-141. https://doi.org/10.1016/j.biortech.2013.02.007.

[28] LIU, P.-R., WANG, T., YANG, Z.-Y., HONG, Y., HOU, Y.-L. 2017. Long-Chain Poly-Arginine Functionalized Porous $\mathrm{Fe}_{3} \mathrm{O}_{4}$ Microspheres as Magnetic Flocculant for Efficient Harvesting of Oleaginous Microalgae. Algal Research, 27, 99-108. https://doi.org/10.1016/j.algal.2017.08.025.

[29] LIU, P.-R., ZHANG, H.-L., WANG, T., YANG, W.-L., HONG, Y., HOU, Y.-L. 2016. Functional Graphene-Based Magnetic Nanocomposites as Magnetic Flocculant for Efficient Harvesting of Oleaginous Microalgae. Algal Research, 19, 86-95. https://doi.org/10.1016/j.algal.2016.07.008.

[30] MATHIMANI, T., MALLICK, N. 2018. A Comprehensive Review on Harvesting of Microalgae for Biodiesel - Key Challenges and Future Directions. Renewable and Sustainable Energy Reviews, 91, 1103-1120. https://doi.org/10.1016/j.rser.2018.04.083.

[31] MOBIN, S., ALAM, F. 2017. Some Promising Microalgal Species for Commercial Applications: A Review. Energy Procedia, 110, 510-517. https://doi.org/10.1016/j.egypro.2017.03.177.

[32] MOLINA GRIMA, E., BELARBI, E.-H., ACIÉN FERNÁNDEZ, F. G., ROBLES MEDINA, A., CHISTI, Y. 2003. Recovery of Microalgal Biomass and Metabolites: Process Options and Economics. Biotechnology Advances, 20(7-8), 491-515. http://www.ncbi.nlm.nih.gov/pubmed/14550018.

[33] PANDEY, M. K., DASGUPTA, CH. N., MISHRA, S., SRIVASTAVA, M., GUPTA, V. K., SUSEELA, M. R., RAMTEKE, P. W. 2019. Bioprospecting Microalgae from Natural Algal Bloom for Sustainable Biomass and Biodiesel Production. Applied Microbiology and 
Biotechnology,103, 5447-5458. https://doi.org/10.1007/s00253-019-09856-2.

[34] PRAGYA, N., PANDEY, K. K., SAHOO, P. K. 2013. A Review on Harvesting, Oil Extraction and Biofuels Production Technologies from Microalgae. Renewable and Sustainable Energy Reviews, 24, 159-171. https://doi.org/10.1016/j.rser.2013.03.034.

[35] PROCHAZKOVÁ, G., ŚAFÁRIK, I., BRANYIK, T. 2013. Harvesting Microalgae with Microwave Synthesized Magnetic Microparticles. Bioresource Technology, 130, 472-477. https://doi.org/10.1016/j.biortech.2012.12.060.

[36] RASTOGI, R. P., PANDEY, A., LARROCHE, CH., MADAMWAR, D. 2018. Algal Green Energy - R\&D and Technological Perspectives for Biodiesel Production. Renewable and Sustainable Energy Reviews, 82, 2946-2969. https://doi.org/10.1016/j.rser.2017.10.038.

[37] RIZWAN, M., MUJTABA, G., MEMON, S. A., LEE, K., RASHID, N. 2018. Exploring the Potential of Microalgae for New Biotechnology Applications and beyond: A Review. Renewable and Sustainable Energy Reviews, 92, 394-404. https://doi.org/10.1016/j.rser.2018.04.034.

[38] SAXENA, P. \& Harish. 2018. Nanoecotoxicological Reports of Engineered Metal Oxide Nanoparticles on Algae. Current Pollution Reports, 4(2), 128-142. https://doi.org/10.1007/s40726-018-0088-6.

[39] SEO, J. Y., KIM, M. G., LEE, K., LEE, Y.-C., NA, J.-G., JEON, S. G., PARK, S. B., OH, Y.-K. 2017. Multifunctional Nanoparticle Applications to Microalgal Biorefinery. In: Rai M., da Silva S. (eds) Nanotechnology for Bioenergy and Biofuel Production. Green Chemistry and Sustainable Technology. Springer, Cham, Switzerland. 370 p. ISBN 978-3-319-45459-7.

[40] SINGH, G., PATIDAR, S. K. 2018. Microalgae Harvesting Techniques: A Review. Journal of Environmental Management, 217, 499-508. https://doi.org/10.1016/j.jenvman.2018.04.010.

[41] SUN, R., SUN, P., ZHANG, J., ESQUIVEL-ELIZONDO, S., WU, Y. 2018. MicroorganismsBased Methods for Harmful Algal Blooms Control: A Review. Bioresource Technology, 248, 12-20. https://doi.org/10.1016/j.biortech.2017.07.175.

[42] TAJABADI, M., KHOSROSHAHI, M. E.. 2013. Effect of Alkaline Media Concentration and Modification of Temperature on Magnetite Synthesis Method Using $\mathrm{FeSO}_{4} / \mathrm{NH}_{4} \mathrm{OH}$. International Journal of Chemical Engineering and Applications, 3(3), 206-210. https://doi.org/10.7763/ijcea.2012.v3.187.

[43] VALVERDE, F., ROMERO-CAMPERO, F. J., ROSA, L., GUERRERO, M. G., SERRANO, A. 2016. New Challenges in Microalgae Biotechnology. European Journal of Protistology, 55, 95101. https://doi.org/10.1016/j.ejop.2016.03.002.

[44] WAN, CH., ALAM, M. A., ZHAO, X.-Q., ZHANG, X.-Y., GUO, S.-L., HO, S.-H., CHANG, J.-S., BAI, F.-W. 2015. Current Progress and Future Prospect of Microalgal Biomass Harvest Using Various Flocculation Technologies. Bioresource Technology, 184, 251-257. https://doi.org/10.1016/j.biortech.2014.11.081.

[45] WANG, S.-K., STILES, A. R., GUO, CH., LIU, CH.-Z. 2015. Harvesting Microalgae by Magnetic Separation: A Review. Algal Research, 9, 178-185. https://doi.org/10.1016/j.algal.2015.03.005.

[46] WANG, T., YANG, W.-L., HONG, Y., HOU, Y.-L. 2016. Magnetic Nanoparticles Grafted with Amino-Riched Dendrimer as Magnetic Flocculant for Efficient Harvesting of Oleaginous Microalgae. Chemical Engineering Journal, 297, 304-314. https://doi.org/10.1016/j.cej.2016.03.038.

[47] XU, L., GUO, CH., WANG, F., ZHENG, S., LIU, CH.-Z. 2011. A Simple and Rapid Harvesting Method for Microalgae by in Situ Magnetic Separation. Bioresource Technology, 102(21), 10047-10051. https://doi.org/10.1016/j.biortech.2011.08.021.

[48] XU, Y., Fu, Y., ZHANG, D. 2017. Cost-Effectiveness Analysis on Magnetic Harvesting of Algal Cells. Materials Today: Proceedings, 4, 50-56. https://doi.org/10.1016/j.matpr.2017.01.192.

[49] YANG, Y., HOU, J., WANG, P., WANG, CH., MIAO, L., AO, Y., XU, Y., et al. 2018. Interpretation of the Disparity in Harvesting Efficiency of Different Types of Microcystis Aeruginosa Using Polyethylenimine (PEI)-Coated Magnetic Nanoparticles. Algal Research, 29, 257-265. https://doi.org/10.1016/j.algal.2017.10.020. 
[50] ZHAO, Y., LIANG, W., LIU, L., LI, F., FAN, Q., SUN, X. 2015. Harvesting Chlorella vulgaris by Magnetic Flocculation Using $\mathrm{Fe}_{3} \mathrm{O}_{4}$ coating with Polyaluminium Chloride and $\begin{array}{llll}\text { Polyacrylamide. } & \text { Bioresource } & \text { Technology, } & \text { 198, }\end{array}$ https://doi.org/10.1016/j.biortech.2015.09.087.

[51] ZHAO, Y., WANG, X., JIANG, X., FAN, Q., LI, X., JIAO, L., LIANG, W. 2018. Harvesting of Chlorella vulgaris Using $\mathrm{Fe}_{3} \mathrm{O}_{4}$ Coated with Modified Plant Polyphenol. Environmental Science and Pollution Research, 25(26), 26246-26258. https://doi.org/10.1007/s11356-018-2677-8.

[52] ZHOU, W., MIN, M., HU, B., MA, X., LIU, Y., WANG, Q., SHI, J., CHEN, P., RUAN, R. 2013. Filamentous Fungi Assisted Bio-Flocculation: A Novel Alternative Technique for Harvesting Heterotrophic and Autotrophic Microalgal Cells. Separation and Purification Technology, 107, 158-165. https://doi.org/10.1016/j.seppur.2013.01.030.

\section{ORCID}

Kristína Gerulová

0000-0003-2588-8627

Alexandra Kucmanová

\author{
0000-0003-3089-7712
}

